\title{
Cytokine-dependent gp130 Receptor Subunit Regulates Human Fetal Pituitary Adrenocorticotropin Hormone and Growth Hormone Secretion
}

\author{
Ilan Shimon, Xinmin Yan, David W. Ray, and Shlomo Melmed \\ Department of Medicine, Cedars-Sinai Research Institute, UCLA School of Medicine, Los Angeles, California 90048
}

\begin{abstract}
We have shown recently that leukemia inhibitory factor (LIF) and oncostatin M (OSM), two members of the gp130dependent cytokine family, stimulate murine proopiomelanocortin (POMC) transcription and adrenocorticotropin hormone (ACTH) secretion. LIF and corticotropin-releasing hormone (CRH) also synergistically induced in vivo ACTH secretion in fetal nonhuman primates. To elucidate the role of the gp130-related cytokines in human pituitary hormone regulation, we tested expression of gp130-related cytokine receptors in human fetal pituitaries. Using RT-PCR, mRNA expression of receptors for LIF, IL-6, and CRH, and the gp130 subunit, were all detected in fetal pituitaries of 18and 31-wk gestation. Recombinant human IL-6, LIF, and OSM treatments of primary human fetal pituitary cultures (16-31 wk) increased ACTH secretion by up to $48 \%(P<$ 0.05) using doses of $1 \mathrm{nM}$, and when fetal cultures were cotreated with CRH, ACTH was induced five- to sixfold as compared to $\mathrm{CRH}$ alone (three- to fourfold; $P=\mathbf{0 . 0 1}$ ). Incubation with gp130-specific antibody suppressed basal and cytokine-stimulated ACTH secretion (alone or with CRH) from human fetal cells. Human POMC promoter $-879 /+6$ fused to the luciferase reporter gene and transfected into AtT-20 cells, was stimulated by LIF (7-fold), which also exerted strong (22-fold) synergy with CRH on POMC transcription. Growth hormone $(\mathrm{GH})$ release from fetal cultures was modestly stimulated $(15-31 \%, P<0.05)$, while other anterior pituitary hormones were not altered by these cytokines. Thus, physiologic concentrations of the gp130-related cytokines have direct effects on ACTH and GH regulation in the human pituitary, indicating that gp130-dependent signals serve as a paracrine system controlling early human pituitary function. (J. Clin. Invest. 1997. 100:357-363.) Key words: fetal pituitary - gp130 - leukemia inhibitory factor • adrenocorticotropin hormone $\bullet$ growth hormone
\end{abstract}

\section{Introduction}

The adenohypophysis abundantly expresses several cytokine types and their respective specific receptors (1-6). TNF $\alpha$, IL-1 and -6 , and leukemia inhibitory factor $(\mathrm{LIF})^{1}$ stimulate the hy-

Address correspondence to Shlomo Melmed, M.D., Division of Endocrinology and Metabolism, Cedars-Sinai Medical Center, 8700 Beverly Blvd., B-131, Los Angeles, CA 90048. Phone: 310-855-4691; FAX: 310-967-0119; E-mail: melmed@CSMC.edu

Received for publication 30 January 1997 and accepted in revised form 11 April 1997.

J. Clin. Invest.

(C) The American Society for Clinical Investigation, Inc.

0021-9738/97/07/0357/07 \$2.00

Volume 100, Number 2, July 1997, 357-363 pothalamic-pituitary-adrenal (HPA) axis in vitro $(7,8)$, and also mediate in vivo ACTH secretion in rats $(9,10)$, primates (11), and humans (12-14). These immunoinflammatory mediators thus activate the HPA axis and interface between the neuroendocrine and immune systems $(7,15)$.

The family of receptors for IL-6, IL-11, LIF, oncostatin M (OSM), ciliary neurotrophic factor (CNTF), and cardiotrophin-1 share the same $130-\mathrm{kD}$ transmembrane signal transduction glycoprotein, gp130 (16-23). These cytokines mediate pleiotropic and redundant biological activities, i.e., each factor exerts multiple effects in different cells, and different cytokines can act on the same cell type to mediate similar effects. These target actions include differentiation, proliferation, and survival of hematopoietic, osteogenic, neuronal, adipogenic, hepatic, and embryonal cells $(8,18-21)$. Cytokine functional redundancy may be explained by the molecular biology of their respective receptors and signal transduction pathways (17). LIF and OSM bind with high affinity to the same receptor complex, consisting of a heterodimer of the low affinity LIF receptor (beta subunit) and the ubiquitously expressed subunit component, gp130 (23), thus explaining the many overlapping biological responses shared by both peptides (24). The existence of OSM-specific receptors consisting of gp130 complexes, however, has been suggested (25), recently cloned, and characterized (26). CNTF also shares the low affinity LIF receptor beta subunit, but for signaling also requires an alpha subunit, as does IL-6. Cardiotrophin-1 also binds to and induces its biological effects via the LIF receptor and gp130 signaling subunits (20). Blocking antibodies to gp130 inhibit responses to CNTF, LIF, and OSM $(21,27)$. Whereas the gp130 signal transduction protein is ubiquitously expressed, expression of the specific cytokine-binding receptor subunits is restricted to specific cell types associated with the observed differences in biological activities of the cytokines.

The intracytoplasmic region of the IL-6 receptor is relatively short, and apparently is not involved in signal transduction. IL-6 ligand triggers association of the IL- 6 receptor subunit and a homodimer consisting of two non-ligand-binding transmembrane gp130 molecules that possess a large intracytoplasmic domain (28). This extracellular association (18) results in cytoplasmic tyrosine kinase activation of gp130, rapid tyrosine phosphorylation of intracellular kinases, and signal transduction (28). As gp130 functions as a common signal transducer for IL-6, LIF, OSM, CNTF, and the other cytokines in this family, gp130 may be a determinant of the common effects elicited by these cytokines in different biological systems.

We have shown previously that LIF and OSM exert synergistic effects with corticotropin-releasing hormone (CRH) to induce proopiomelanocortin (POMC) transcription and $\mathrm{ACTH}$

1. Abbreviations used in this paper: $\mathrm{CNTF}$, ciliary neurotrophic factor; $\mathrm{CRH}$, corticotropin-releasing hormone; $\mathrm{GH}$, growth hormone; LIF, leukemia inhibitory factor; OSM, oncostatin M; POMC, proopiomelanocortin; PRL, prolactin; RT, reverse transcriptase. 
secretion from murine pituicytes $(5,29-31)$. LIF also stimulated acute ACTH secretion in fetal nonhuman primates (11), whereas disruption of the LIF gene in mice by the knockout approach resulted in attenuated ACTH response to stress, which was restored by LIF replacement (32). When taken together with reports (12-14) that IL-6 stimulates in vivo ACTH secretion in humans, these observations indicate that cytokines sharing gp130 as a signaling receptor subunit may be involved directly in human ACTH regulation. We, therefore, studied the in vitro direct effects of LIF, OSM, and IL-6 on human fetal anterior pituitary cells. We demonstrate here that gp130mediated signaling regulates human pituitary hormone secretion and POMC transcription.

\section{Methods}

Peptides and antibodies. Recombinant human LIF and OSM were obtained from R \& D Systems, Inc. (Minneapolis, MN). Recombinant human IL-2 and IL-6 were obtained from Sigma Chemical Co. (St. Louis, MO). Goat anti-human soluble gp130 IgG was obtained from R \& D Systems Inc., preimmune goat IgG was from Sigma, and human CRH was purchased from American Peptide Company Inc. (Sunnyvale, CA).

Human fetal pituitary tissue. Human fetal tissues (16-31-wk gestation) were obtained from an independent facility for therapeutic pregnancy termination, with no direct or indirect involvement of our investigators in the third party termination referral. Studies of human tissues followed guidelines of the National Advisory Board on Ethics in Reproduction. Written informed consent was obtained for anonymous distribution of aseptic tissue specimens.

Human LIF, IL-6, and CRH receptors, and gp130 subunit $m R N A$ expression. Normal adult human pituitary glands (obtained from Zion Diagnostics, New York), and fetal pituitaries (18- and 31-wk gestation) were harvested and kept at $-70^{\circ} \mathrm{C}$ for RNA extraction. Tissues were homogenized, and total RNA was extracted using TRIzol (GIBCO BRL, Gaithersburg, MD). Reverse transcriptase (RT) followed by PCR amplification was performed as previously reported (33) to detect human growth hormone (GH), LIF receptor, IL-6 receptor, CRH receptor, and gp130 subunit mRNA expression. In brief, $1 \mu \mathrm{g}$ of each RNA sample was treated (amplification grade DNase 1; GIBCO BRL) to eliminate contaminating genomic DNA. RNA then was used in a $20-\mu l$ RT reaction containing Oligo(dt)16 as a primer, and SuperScript II (GIBCO BRL). RT incubation was for $50 \mathrm{~min}$ at $42^{\circ} \mathrm{C}$. Samples were also incubated without RT enzyme as negative controls. $1-\mu 1$ aliquots from the generated cDNA and the negative control reactions were used for subsequent PCR amplification in the presence of $1.5 \mathrm{mmol} / \mathrm{liter} \mathrm{MgCl}_{2}(2.5 \mathrm{mmol} / \mathrm{liter}$ for IL-6 receptor) and $5 \mathrm{U}$ Taq DNA polymerase (GIBCO BRL). Amplifications were carried out for 38-40 cycles, with an initial denaturation step at $95^{\circ} \mathrm{C}$ for $5 \mathrm{~min}$, and a final 7 -min extension step at $72^{\circ} \mathrm{C}$. Each cycle consisted of denaturation at $94^{\circ} \mathrm{C}$, annealing $\left(60^{\circ} \mathrm{C}\right.$ for $\mathrm{GH}, 55^{\circ} \mathrm{C}$ for LIF receptor, $58^{\circ} \mathrm{C}$ for IL-6 receptor and gp130 subunit, and $64^{\circ} \mathrm{C}$ for $\mathrm{CRH}$ receptor), and elongation at $72^{\circ} \mathrm{C}$, each step for $1 \mathrm{~min}$. The following primer sets were used: GH, 5'-CTTTTTGACAACGCTAGTCTC (exon 1, 453-473) and 3'-CAGGCTGTTGGCGAAGACACT (exon 3, 1013-1033) (34); LIF receptor, 5'-AAGATATAGCTGCAGAAGAGG (3219-3239) and $3^{\prime}$-TAACAATACTTCACAGGAT (3559-3577) (19); IL-6 receptor, 5'-GAGACAGCGTGACTCTGACCT (556-576) and 3'-CCGGACTGTTCTGAAACTTCC (889-909) (35); gp130 subunit, 5'-CATGCTTTGGGTGGAATGGAC (1566-1586) and 3'-CATCAACAGGAAGTTGGTCCC (1871-1891) (16); and CRH receptor, 5'-CATCCGGTGCCTGCGAAACA (664-683) and 3'-GGCCCTGGTAGATGTAGTCG (1030-1049) (36). The PCR products thus generated are 279 (GH), 359 (LIF receptor), 354 (IL-6 receptor), 326 (gp130 subunit), and $386 \mathrm{bp}$ (CRH receptor). The PCR product of human LIF receptor was digested by AvaII, the DNA product of the IL-6 receptor by BstXI, human gp130 by KpnI, and the CRH receptor by FspI restriction enzyme (all enzymes obtained from GIBCO BRL). The PCR products were visualized with ethidium bromide after electrophoresis on $1.8 \%$ agarose gel.

Primary fetal pituitary cell culture. Specimens were harvested within $0.5-2 \mathrm{~h}$ of the termination procedure. Fetal pituitary was washed in low glucose DME supplemented with $0.3 \%$ BSA, 2 mM glutamine, and penicillin/streptomycin, and was then minced and enzymatically dissociated using $0.35 \%$ collagenase and $0.1 \%$ hyaluronidase (both from Sigma Chemical Co.) for 45-60 min. Cell suspensions were filtered and resuspended in low glucose DME supplemented with $10 \%$ FBS, $2 \mathrm{mM}$ glutamine, and antibiotics. For primary cultures, $\sim 5 \times 10^{4}$ cells were seeded in 48-well tissue culture plates (Costar Corp., Cambridge, MA) in $0.5 \mathrm{ml}$ medium, and were incubated for $72-96 \mathrm{~h}$ in a humidified atmosphere of $95 \%$ air $/ 5 \% \mathrm{CO}_{2}$ at $37^{\circ} \mathrm{C}$. Medium was then changed to serum-free defined low glucose DME containing $0.2 \%$ BSA, $120 \mathrm{nM}$ transferrin, $100 \mathrm{nM}$ hydrocortisone, $0.6 \mathrm{nM}$ triiodothyronine, $5 \mathrm{U} /$ liter insulin, $3 \mathrm{nM}$ glucagon, $50 \mathrm{nM}$ parathyroid hormone, $2 \mathrm{mM}$ glutamine, $15 \mathrm{nM}$ EGF, and antibiotics, and cells were treated for $24 \mathrm{~h}$ with LIF, OSM, IL-6, or IL-2 (concentration of $1 \mathrm{nM})$, with or without $\mathrm{CRH}(10 \mathrm{nM})$, after which medium was collected and stored at $-20^{\circ}$ for later hormone measurements. A single pituitary was divided and plated into 40-60 wells, depending upon the age and size of the specimen, and was used for one experiment where 6-7 wells served as controls (treated with vehicle solution), and groups of 6-7 wells were treated with specific cytokines and/or CRH. Time-dependent (6 h, $24 \mathrm{~h})$ experiments were performed. Experiments were also performed using goat anti-human gp130 IgG, where cells were incubated with anti-gp130 or preimmune goat $\mathrm{IgG}$ at concentrations of $100 \mu \mathrm{g} / \mathrm{ml}$ serum-free defined medium for $24 \mathrm{~h}$ in the presence of added agents.

Hormone assays. RIA for human GH was performed using a kit purchased from Diagnostics Products Corp. (Los Angeles, CA) after 1:5 dilution of the collected primary culture medium. Human ACTH (1:3 dilution) was measured by immunoradiometric assay (IRMA) (Diagnostic Systems Laboratories, Inc., Webster, TX), and thyroid-stimulating hormone (no dilution) and prolactin (PRL) (no dilution) levels were measured by IRMA (Diagnostics Products Corp.). RIA for intact lutenizing hormone ( $\mathrm{LH})$ was performed using reagents provided by the National Hormone and Pituitary Program, National Institute of Diabetes and Digestive and Kidney Diseases (Bethesda, MD).

Transcription studies. Full-length human POMC-luc $(-879 /+6)$ reporter plasmid was the kind gift of Dr. M. Low (Vollum Institute, Portland, OR). AtT-20 cells were obtained from the American Type Culture Collection (Rockville, MD), and grown in DME supplemented with $10 \%$ FCS, $2 \mathrm{mM}$ glutamine, and antibiotics. Transient transfection using lipofectin was performed as described (29). In brief, cells were washed with serum-free medium, and were incubated with DNA $(2 \mu \mathrm{g} / 2-\mathrm{ml}$ well) and lipofectin (GIBCO BRL) for $5 \mathrm{~h}$, at which time medium was changed to DME containing glutamine and BSA $0.1 \%$. Treatments were added after $16 \mathrm{~h}$, and cells were harvested $6 \mathrm{~h}$ later. Cell lysis buffer contained $25 \mathrm{mM}$ Tris phosphate (pH 7.8), $10 \mathrm{mM} \mathrm{MgCl}_{2}, 0.1 \% \mathrm{BSA}, 15 \%$ glycerol, $1 \%$ Triton X-100, and $1 \mathrm{mM}$ EDTA. Luciferase activity was measured in the presence of $0.8 \mathrm{mM}$ ATP and $0.3 \mathrm{mM}$ D-luciferin (Berthold Lumat LB $9501 \mathrm{lu}-$ minometer; Wallac, Inc., Gaithersburg, MD), and light emission integrated over $15 \mathrm{~s}$.

Statistical analysis. Results are expressed as mean \pm SEM. Differences were assessed by the unpaired $t$ test or one-way ANOVA when appropriate. For both statistical tests, $P<0.05$ was considered significant.

\section{Results}

Receptor $m R N A$ expression in human pituitaries. RNA extracted from human adult pituitary and fetal pituitaries (18- 

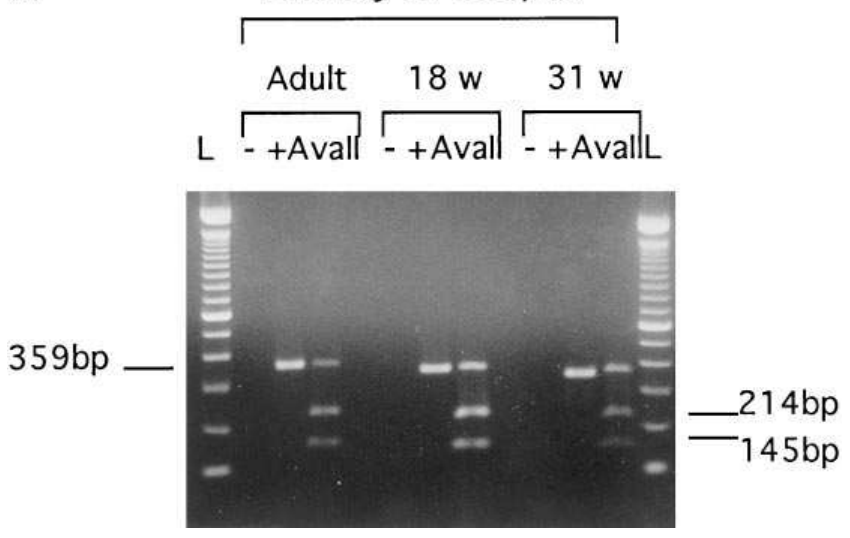

C
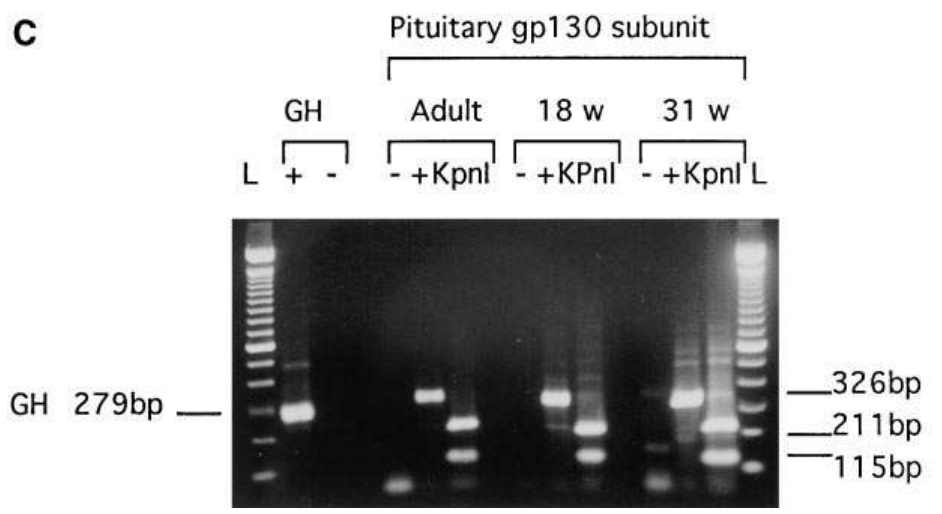

B
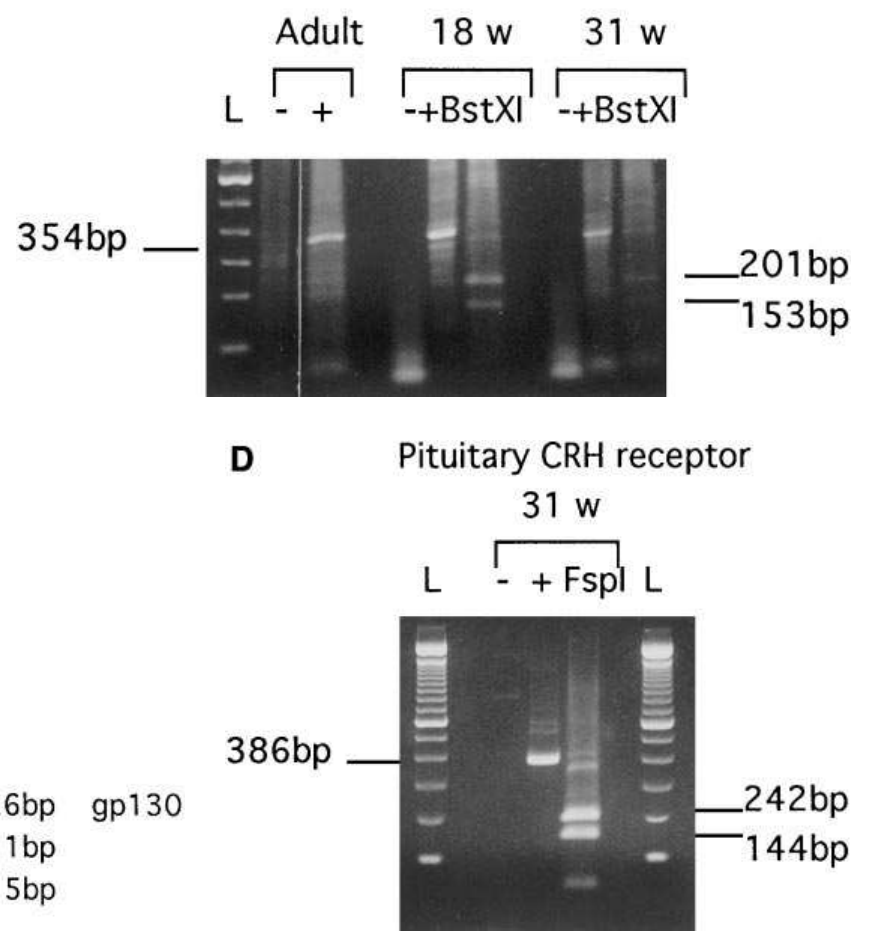

Figure 1. Human LIF receptor $(A)$, IL-6 receptor $(B)$, gp130 receptor subunit $(C)$, and CRH receptor mRNA expression $(D)$ in adult human pituitary, and in 18- and 31-wk gestation human fetal pituitaries. Extracted RNA ( $1 \mu \mathrm{g} / \mathrm{reaction})$ was treated with deoxyribonuclease, and was subjected to reverse transcription using Oligo(dT) as primer. Samples incubated without RT enzyme served as controls. Aliquots from the generated cDNAs and negative controls were subjected to subsequent PCR amplification (38-40 cycles) of LIF, IL-6, and CRH receptors, gp130 subunit, and human GH using the primer pairs indicated in Methods. PCR products and enzyme digestion products were resolved on a $1.8 \%$ agarose gel. The expected PCR products of LIF receptor (359-bp band, digested by AvaII), IL-6 receptor (354 bp, digested by BstXI), gp130 subunit (326 bp, digested by KpnI), and CRH receptor (386 bp, digested by FspI) are shown in $A-D$, respectively. Human GH RNA expression (279-bp band; $C$ ) confirmed the pituitary origin of the studied mRNA. $L, 100$-bp ladder; +, with RT; -, no RT added.

and 31-wk gestation) was subjected to RT followed by PCR amplification. Results of the PCR reaction revealed the presence of human LIF receptor (359 bp), IL-6 receptor (354 bp), gp130 subunit (326 bp), and CRH receptor (386 bp) (Fig. 1, $A-D$, respectively) in adult pituitary and fetal glands of both 18- and 31-wk gestation. To confirm the pituitary origin of the mRNA, testing for GH expression in these tissues resulted in a 279-bp PCR product, as expected (Fig. 1 C). Specificity of expressed bands was confirmed by restriction enzyme digestion. The 359- and 354-bp bands representing LIF receptor and IL-6 receptor expression in the different pituitary preparations were appropriately digested by AvaII to 214- and 145-bp restriction products (Fig. $1 A$ ), and by BstXI to 201- and 153-bp DNA products (Fig. $1 B$ ), respectively. The human gp130 subunit and the $\mathrm{CRH}$ receptor PCR products were cut by KpnI (to 115- and 211-bp bands, Fig. $1 C$ ) and FspI (144 and 242-bp products, Fig. $1 \mathrm{D}$ ), respectively. All sample products were negative when reactions without RT were amplified by PCR, thus confirming that the positive PCR product bands represent the presence of specific pituitary mRNA transcripts.

gp130-dependent cytokines stimulate ACTH in human fetal pituitary. To determine the effect of LIF, OSM, and IL-6 on
ACTH secretion from normal human pituitary cells, primary cultures of human fetal pituitary cells (16-31-wk gestation) were incubated for $24 \mathrm{~h}$ with the different cytokines, alone or in the presence of CRH. LIF $(1 \mathrm{nM})$ induced $29 \%$ induction in ACTH secretion $(P<0.05)$ over controls, CRH $(10 \mathrm{nM})$ alone induced the expected three- to fourfold induction of ACTH (37), and combination of the two compounds was synergistic, stimulating ACTH production five- to sixfold $(P=0.01$ versus $\mathrm{CRH}$ alone; Fig. 2). Similar stimulations of ACTH were demonstrated when pituitary cells derived from different gestational periods $(23,24$, and $31 \mathrm{wk})$ were used for these experiments. The cytokine did not alter ACTH during $6 \mathrm{~h}$ of incubation, and required 24-h treatment to induce ACTH. Similarly, OSM (1 nM) mildly induced ACTH release (13\%, NS). When OSM was incubated together with $\mathrm{CRH}$, however, ACTH production was increased by $37 \%$ above levels induced by $\mathrm{CRH}$ alone $(P<0.05$; Fig. 2). IL-6 $(1 \mathrm{nM})$ increased ACTH secretion by $48 \%(P=0.005)$. Furthermore, when CRH and IL-6 were added for $24 \mathrm{~h}$ to the cell cultures, ACTH secretion was stimulated by $80 \%$ above levels induced by $\mathrm{CRH}$ alone $(P<0.05$; Fig. 2). In contrast to these cytokines, IL-2, which does not signal through gp130, had no stimulatory effect on ACTH release 


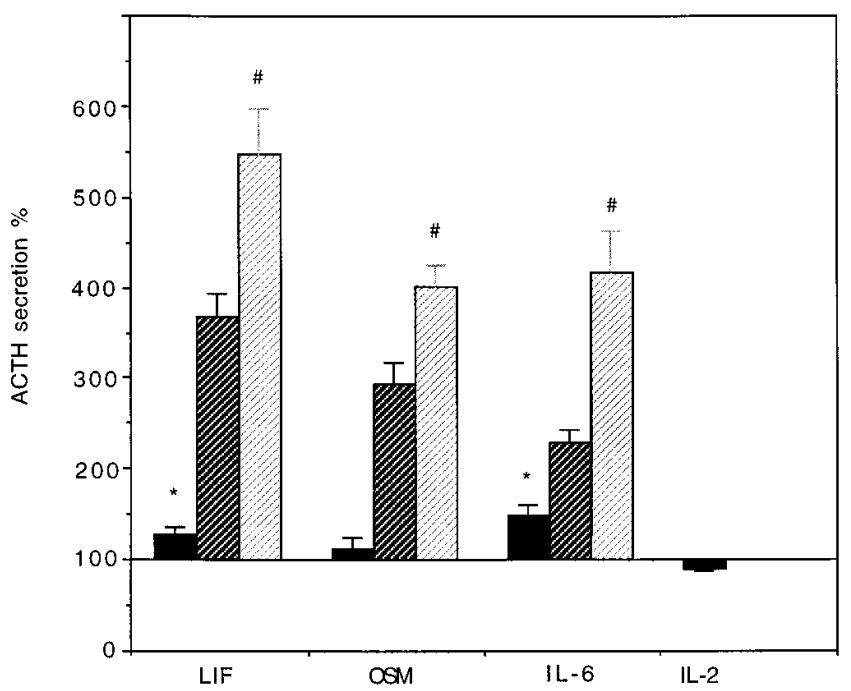

Figure 2. Effects of LIF, OSM, IL-6, IL-2 (1 nM each), and CRH $(10 \mathrm{nM})$ on human ACTH secretion. Human fetal pituitary cells in dispersed primary cultures were incubated for $24 \mathrm{~h}$ with the indicated cytokines alone or in combination with $\mathrm{CRH}$, in serum-free medium. Results are expressed as percent change over vehicle-treated control wells $(100 \%)$. Each bar represents mean ( \pm SEM) of ACTH secretion in five to six wells. ${ }^{*} P<0.05$, versus vehicle-treated controls; ${ }^{\#} P<$ 0.05 , versus CRH-treated cells. Black bar, cytokine (1 nM); dark striped bar, CRH (10 nm); light striped bar, cytokine + CRH.

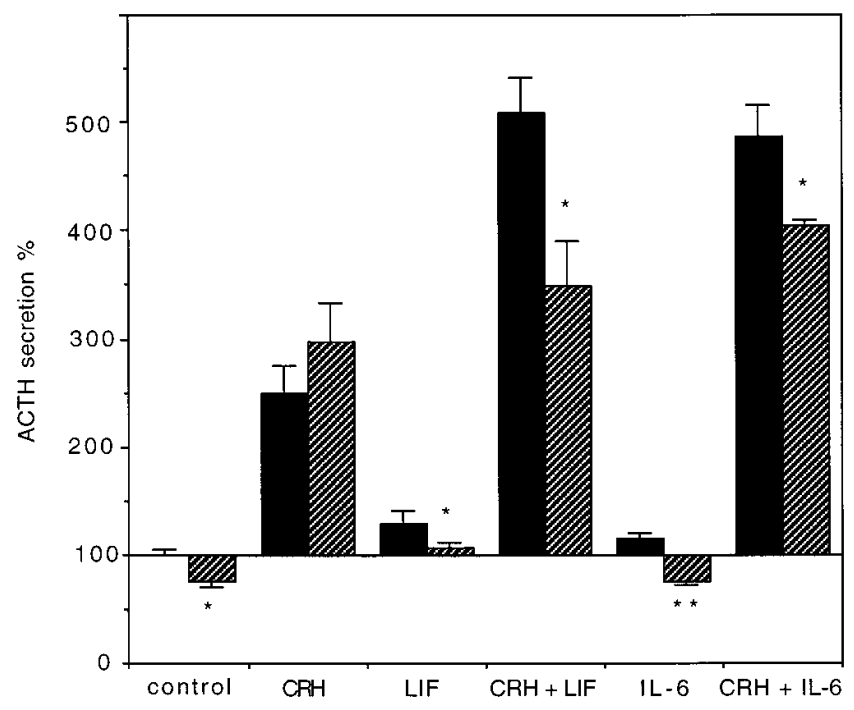

Figure 3. Effects of anti-human gp130 IgG on human ACTH secretion. Primary cultures of human fetal pituitary cells were incubated for $24 \mathrm{~h}$ with goat anti-gp130 $\operatorname{IgG}(100 \mu \mathrm{g} / \mathrm{ml})$ or preimmune goat $\operatorname{IgG}(100 \mu \mathrm{g} / \mathrm{ml})$, and $1 \mathrm{nM}$ of each of the indicated cytokines (alone or in combination with $10 \mathrm{nM} \mathrm{CRH}$ ), in serum-free medium. Results are expressed as percent change over normalized controls (100 $\pm 5 \%)$. Each bar represents mean $( \pm$ SEM) of ACTH secretion in four to six wells. Black bar, control; striped bar, anti-gp130. $* P \leq 0.05 ; * * P<$ 0.005 .

expression and regulation of the human POMC gene (38). $1 \mathrm{nM}$ LIF exerted a 7-fold induction of reporter activity (Fig. 4), whereas CRH $(10 \mathrm{nM})$ stimulated the expected 3.5-fold increase in the human POMC transcription. The combination of CRH (10 nM) and LIF (1 nM), however, was synergistic, inducing a 22-fold stimulation in reporter gene activity over vehicle-treated control cells (Fig. 4).

Cytokine stimulation of $\mathrm{GH}$ secretion from human fetal pituitary cell cultures. LIF, OSM, and IL-6 (1 nM) also caused a significant $15-31 \%$ induction in GH secretion from primary fetal pituitary cultures after $24 \mathrm{~h}(P<0.05$; Fig. 5). The cytokines, however, did not alter PRL, thyroid-stimulating hormone, and LH secretion from primary cultures of human fetal anterior pituitary cells.

\section{Discussion}

This study shows that physiologic concentrations of human LIF, OSM, and IL-6, the members of the cytokine family that induce their biological effects via receptors associated with the common signal transducer gp130, directly stimulate ACTH and $\mathrm{GH}$ secretion in human fetal pituitary cells. Moreover, the cytokines have synergistic effects on ACTH secretion and POMC transcription when combined with CRH. The effects of the gp130-related cytokines on ACTH secretion were blocked by specific antibody to the human gp130 subunit. The gp130dependent cytokines therefore regulate ACTH and GH production and release from the human pituitary.

For our studies we used primary cultures of human fetal pituitaries obtained at the second trimester. At this time, the hormone-producing cells including corticotrophs and soma- 


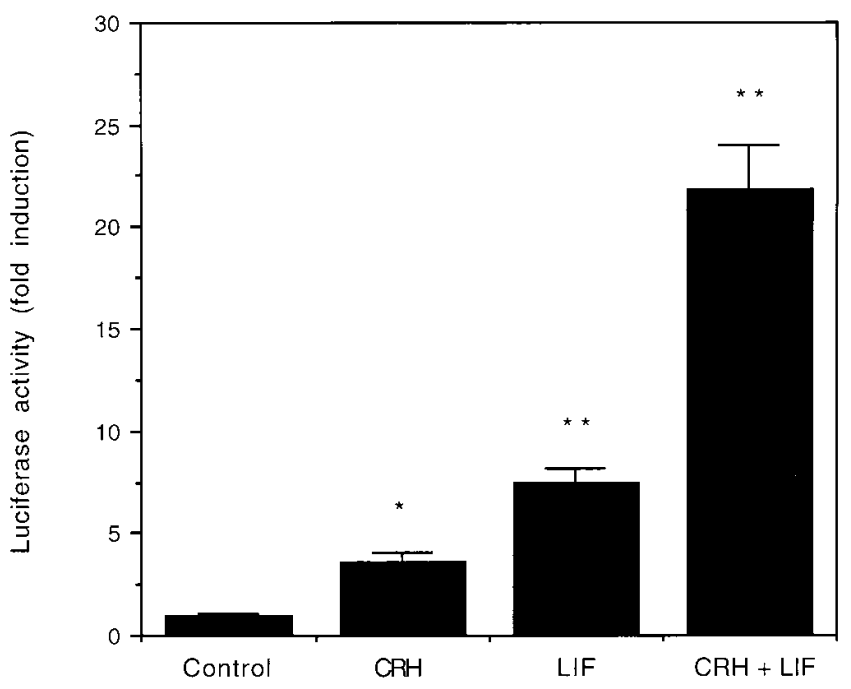

Figure 4. LIF and CRH effects on human POMC transcription. Human POMC gene promoter $(-879 /+6)$ was fused to the luciferase reporter, and was transiently transfected into AtT-20 cells using lipofectin. After $16 \mathrm{~h}$, cells were treated with vehicle (control), LIF (1 nM), CRH $(10 \mathrm{nM})$, or both LIF $(1 \mathrm{nM})$ and CRH $(10 \mathrm{nM})$ in serum-free medium for $6 \mathrm{~h}$. The effects of the different treatments on human POMC promoter activity are expressed as fold induction of luciferase activity over control, mean of three wells $( \pm$ SEM), from a representative experiment repeated three times. $* P<0.01 ; * * P<0.0001$.

totrophs are well-differentiated (39). Corticotrophs are the first hormone-secreting cells recognized in the human fetal anterior pituitary, and are evident by 6 wk of gestation (39). GH immunoreactivity is identified in well-differentiated somatotrophs by $8 \mathrm{wk}$ (39). ACTH and GH are released from hu-

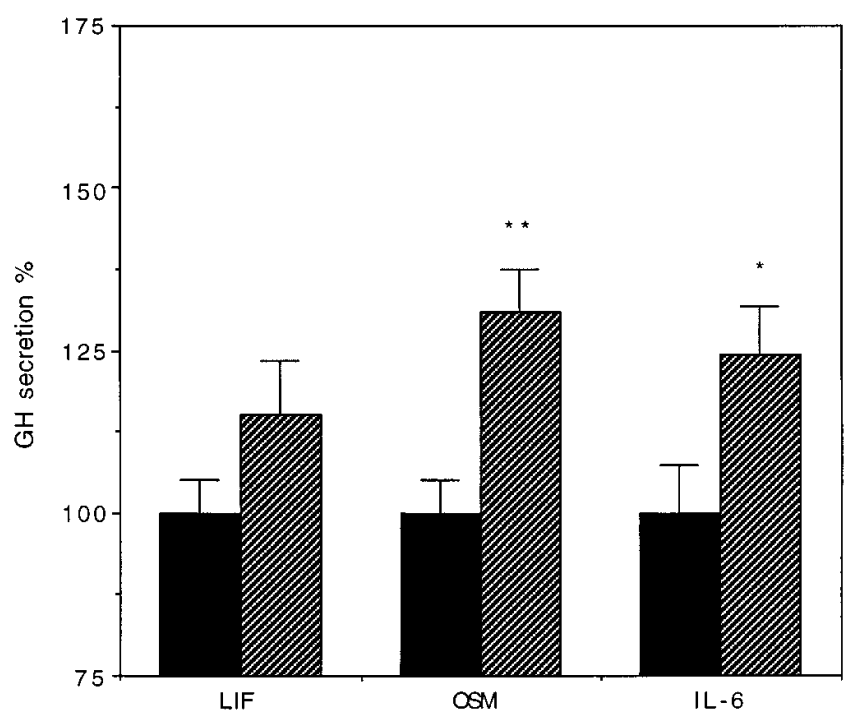

Figure 5. Effects of LIF, OSM, and IL-6 on human GH secretion. Primary cultures of human fetal pituitaries were incubated for $24 \mathrm{~h}$ with $1 \mathrm{nM}$ of the indicated cytokines in serum-free medium. Results are expressed as percent change over vehicle-treated control wells $(100 \%)$. Each bar represents mean $( \pm$ SEM $)$ of GH secretion in five to six wells. Black bar, control; striped bar, cytokine $(1 \mathrm{~nm}) . * P<$ $0.05 ; * * P<0.005$. man fetal pituitary cultures at 7 and 9 wk of gestation, respectively (39), and at the second trimester significant levels of these hormones are measurable in fetal pituitary culture medium (5). Fetal corticotrophs and somatotrophs are responsive to hypothalamic releasing and inhibitory factors, including $\mathrm{CRH}$, growth hormone-releasing hormone, and somatostatin, as early as 12-14 wk (39). Thus, these observations support the functional maturity and appropriate responsiveness to hypothalamic regulation of the fetal pituicytes used in these studies. In the present study we demonstrate the expression of $\mathrm{CRH}$, LIF, and IL-6 receptors and the gp130 subunit in fetal pituitary tissue at 18-31-wk gestation (Fig. 1). We used RT-PCR for these mRNA expression studies, as Northern or ribonuclease protection assays are limited by the amount of RNA required for analysis. Interestingly, LIF and LIF receptor are expressed abundantly in human corticotrophs and somatotrophs, whereas their expression is less prevalent in lactotrophs and gonadotrophs (5). Moreover, ACTH- and GH-producing adenomas were strongly immunopositive for LIF, compared with negligible LIF staining in PRL-secreting and nonfunctioning pituitary adenomas (5). Thus, to gain insight into ACTH and GH regulation by gp130-related cytokines, we used fetal pituitary cell cultures as a unique model of functional human pituitary tissue. These are mature hormone-producing cells that express the relevant cytokine receptors, and the common gp130 signal transducer.

IL-6 stimulates PRL, GH, and gonadotropin secretion from primary rat pituitary cultures (40-42), and also may induce ACTH release under certain conditions (42-44). More evidence, however, supports the in vivo involvement of IL-6 in ACTH secretion (45). Intravenous administration of recombinant human or murine IL-6 to rats resulted in a three- to fourfold increase in plasma ACTH levels within 30 min after injection $(10,43)$. In humans, subcutaneous or intravenous injection of IL-6 markedly increased ACTH and cortisol levels on the first day of cytokine administration (12-14), with no detectable change in circulating $\mathrm{CRH}$ concentrations that were close to the lower limit of assay detection $(12,14)$. In vitro and in vivo experiments in animals, however, showed that a central mechanism is involved in ACTH stimulation in response to IL-6 (43), and that IL-6 stimulates hypothalamic CRH secretion $(46,47)$. Thus, IL-6 that is presumably produced by the folliculo-stellate cells of the anterior pituitary $(48,49)$ induces both ACTH and CRH. Moreover, dexamethasone, which also suppresses pituitary ACTH, dose-dependently inhibits release of IL-6 from cultured anterior pituitary cells (50). Thus, the pituitary negative feedback regulation by glucocorticoids may include paracrine mechanisms in addition to direct glucocorticoid response element-mediated suppression of POMC.

Available data on IL-6 effects on anterior pituitary hormone secretion are derived from rodent pituitary cell cultures or in vivo studies in animals and humans. In this study we show for the first time that IL-6, LIF, and OSM have direct stimulatory effects on human ACTH and GH secretion from normal anterior pituitary tissue. Moreover, these cytokines appear to amplify the ACTH response to $\mathrm{CRH}$. For these studies we used cytokine doses $(\sim 1 \mathrm{nM})$ within the calculated $K_{\mathrm{d}}$ of cellular binding sites for IL-6 (18), LIF, and OSM (25). In contrast to the well-described effects of IL- 6 on pituitary hormone secretion, LIF and OSM have been the subjects of only a limited number of recent studies, indicating their role in pituitary hormone regulation. LIF and OSM stimulate both in vitro 
POMC gene transcription and ACTH secretion in AtT-20 cells $(5,29)$, and LIF stimulates ACTH secretion in primary mouse pituitary cell cultures (30) and in fetal nonhuman primates in vivo (14). The present study, however, is the first report on the effects of IL-6, LIF, and OSM on normal human pituitary tissue. The similar pituitary effects of these three structurally and functionally related cytokines are not surprising, as they share the gp130 component as a common signal transducer, and mediate similar functions in several tissues $(8,17,51)$. Moreover, using monoclonal antibodies specific for the human gp130 subunit, we partially blocked the response of the pituitary to both IL-6 and LIF. This effect is similar to the suppression of their hematopoietic and neurotrophic functions by the neutralizing antibodies $(21,26,52)$, and demonstrates that gp130 is required for both IL-6- and LIF-signaling processes in the human pituitary. Thus, these related cytokines bind to their specific receptors on the pituicytes, but for signaling share the common gp130 subunit, and may function in a redundant or overlapping manner. We did not study other members of this cytokine family including IL-11, CNTF, and cardiotrophin-1, but they may have similar effects on hormone secretion in human fetal pituitary cultures. Interestingly, in the absence of added cytokines, anti-gp130 serum suppressed basal ACTH release by $25 \%$ (Fig. 3), consistent with the functioning of an endogenous autocrine LIF and IL-6 effect on ACTH in the human pituitary corticotroph. As both these cytokines are expressed locally in the pituitary $(1,3,5)$, this inhibitory effect of the antibody reflects a blocked endogenous cytokine action.

The stimulatory effect of LIF on human ACTH secretion during $24 \mathrm{~h}$ may be explained by enhancement of POMC transcription (Fig. 4). This effect is also supported by the absence of ACTH stimulation after a 6-h incubation with LIF. We have recently shown a similar induction of rat POMC transcription by LIF and OSM (29). Moreover, CRH synergizes with the gp130-dependent cytokines in inducing human POMC transcription and ACTH secretion from fetal pituitary cells. Whereas the effect of the cytokines on basal ACTH was mild (Fig. 2), LIF, OSM, and IL-6 exerted striking synergy with $10 \mathrm{nM} \mathrm{CRH}$ to induce ACTH release. Interestingly, similar synergy between LIF and CRH was demonstrated in fetal nonhuman primates, resulting in up to 23 -fold induction of ACTH secretion in vivo (14).

As we have shown that LIF receptors are also expressed on human fetal somatotrophs (5), we therefore studied effects of these cytokines on GH secretion from fetal pituitary cultures. IL-6, OSM, and LIF all modestly stimulated GH secretion from normal pituitary cells. Thus, the gp130-related cytokines may also regulate $\mathrm{GH}$ secretion $(40,42)$.

These results indicate that in addition to regulation of fetal pituitary development and function by hypothalamic factors, local cytokine signals also modulate expression of human fetal pituitary hormones. Similar stimulatory effects were observed for cytokines that share a common signal transduction mechanism, thus emphasizing that functional gp130-associated receptors are expressed in the human fetal pituitary. Their respective ligands and the signaling they exert reflect an immunoendocrine interface for stress-induced neuroendocrine responses. Thus, intrauterine neuroendocrine stress signaling pathways appear to be operative in the human fetus, and gp130-dependent postreceptor signaling may serve as an additional paracrine system controlling human pituitary function.

\section{Acknowledgments}

The authors are grateful to Dr. M. Low for providing the full-length human POMC promoter.

This work was supported by National Institutes of Health grant DK-50238 (S. Melmed), and by the Doris Factor Molecular Endocrinology Laboratory.

\section{References}

1. Spangelo, B.L., P.D. deHoll, L. Kalabay, B.R. Bond, and P. Arnaud. 1994. Neurointermediate pituitary lobe cells synthesize and release interleukin-6 in vitro: effects of lipopolysaccharide and interleukin-1 $\beta$. Endocrinology. 135:556-563.

2. Koenig, J.I., K. Snow, B.D. Clark, R. Toni, J.G. Cannon, A.R. Shaw, C.A. Dinarello, S. Reichlin, S.L. Lee, and R.M. Lechan. 1990. Intrinsic pituitary interleukin-1 $\beta$ is induced by bacterial lipopolysaccharide. Endocrinology. 126: 3053-3058.

3. Velkeniers, B., P. Vergani, J. Trouillas, J. D'Haens, R.J. Hooghe, and E.L. Hooghe-Peters. 1994. Expression of IL-6 mRNA in normal rat and human pituitaries and in human pituitary adenomas. J. Histochem. Cytochem. 42:67-76.

4. Arzt, E., G. Stelzer, U. Renner, M. Lange, O.A. Muller, and G.K. Stalla. 1992. Interleukin-2 and interleukin-2 receptor expression in human corticotrophic adenoma and murine pituitary cell cultures. J. Clin. Invest. 90:19441951.

5. Akita, S., J. Webster, S.G. Ren, H. Takino, J. Said, O. Zand, and S. Melmed. 1995. Human and murine pituitary expression of leukemia inhibitory factor. Novel intrapituitary regulation of adrenocorticotropin hormone synthesis and secretion. J. Clin. Invest. 95:1288-1298.

6. Wang, Z., S.G. Ren, and S. Melmed. 1996. Hypothalamic and pituitary leukemia inhibitory factor gene expression in vivo: a novel endotoxin-inducible neuro-endocrine interface. Endocrinology. 137:2947-2953.

7. Chrousos, G.P. 1995. The hypothalamic-pituitary-adrenal axis and immune-mediated inflammation. N. Engl. J. Med. 332:1351-1362.

8. Benigni, F., G. Fantuzzi, S. Sacco, M. Sironi, P. Pozzi, C.A. Dinarello, J.D. Sipe, V. Poli, M. Cappelletti, G. Paonessa, et al. 1996. Six different cytokines that share gp130 as a receptor subunit, induce serum amyloid $\mathrm{A}$ and potentiate the induction of interleukin- 6 and the activation of the hypothalamuspituitary-adrenal axis by interleukin-1. Blood. 87:1851-1854.

9. Rivier, C., W. Vale, and M. Brown. 1989. In the rat, interleukin $1 \alpha$ and $\beta$ stimulate ACTH and catecholamine release. Endocrinology. 125:3090-3102.

10. Naitoh, Y., J. Fukata, T. Tominaga, Y. Nakai, S. Tamai, K. Mori, and H. Imura. 1988. Interleukin-6 stimulates the secretion of adrenocorticotrophic hormone in conscious, freely moving rats. Biochem. Biophys. Res. Commun. 155: 1459-1463.

11. Akita, S., P.M. Conn, and S. Melmed. 1996. Leukemia inhibitory factor (LIF) induces acute adrenocorticotrophic hormone (ACTH) secretion in fetal rhesus macaque primates: a novel dynamic test of pituitary function. J. Clin. Endocrinol. Metab. 81:4170-4173.

12. Mastorakos, G., G.P. Chrousos, and J.S. Weber. 1993. Recombinant interleukin-6 activates the hypothalamic-pituitary-adrenal axis in humans. J. Clin. Endocrinol. Metab. 77:1690-1694.

13. Spath-Schwalbe, E., J. Born, H. Schrezenmeier, S.R. Bornstein, P. Stromeyer, S. Drechsler, H.L. Fehm, and F. Porzsolt. 1994. Interleukin-6 stimulates the hypothalamus-pituitary-adrenocortical axis in man. J. Clin. Endocrinol. Metab. 79:1212-1214.

14. Mastorakos, G., J.S. Weber, M.A. Magiakou, H. Gunn, and G.P. Chrousos. 1994. Hypothalamic-pituitary-adrenal axis activation and stimulation of systemic vasopressin secretion by recombinant interleukin-6 in humans: potential implications for the syndrome of inappropriate vasopressin secretion. $J$. Clin. Endocrinol. Metab. 79:934-939.

15. Imura, H., J. Fukata, and T. Mori. 1991. Cytokines and endocrine function: an interaction between the immune and neuroendocrine systems. Clin. Endocrinol. 35:107-115.

16. Hibi, M., M. Murakami, M. Saito, T. Hirano, T. Taga, and T. Kishimoto. 1990. Molecular cloning and expression of an IL-6 signal transducer, gp130. Cell. 63:1149-1157.

17. Kishimoto, T., T. Taga, and S. Akira. 1994. Cytokine signal transduction. Cell. 76:253-262.

18. Taga, T., M. Hibi, Y. Hirata, K. Yamasaki, K. Yasukawa, T. Matsuda, T. Hirano, and T. Kishimoto. 1989. Interleukin-6 triggers the association of its receptor with a possible signal transducer, gp130. Cell. 58:573-581.

19. Gearing, D.P., C.J. Thut, T. VandenBos, S.D. Gimpel, P.B. Delaney, J. King, V. Price, D. Cosman, and M.P. Beckman. 1991. Leukemia inhibitory factor receptor is structurally related to the IL-6 signal transducer, gp130. EMBO (Eur. Mol. Biol. Organ.) J. 10:2839-2848.

20. Pennica, D., K.J. Shaw, T.A. Swanson, M.W. Moore, D.L. Shelton, K.A. Zioncheck, A. Rosenthal, T. Taga, N.F. Paoni, and W.I. Wood. 1995. Cardiotrophin-1. Biological activities and binding to the leukemia inhibitory factor receptor/gp130 signaling complex. J. Biol. Chem. 270:10915-10922. 
21. Ip, N.Y., S.H. Nye, T.G. Boulton, S. Davis, T. Taga, Y. Li, S.J. Birren, K. Yasukawa, T. Kishimoto, D.J. Anderson, et al. 1992. CNTF and LIF act on neuronal cells via shared signaling pathways that involve the IL-6 signal transducing receptor component gp130. Cell. 69:1121-1132.

22. Yin, T., T. Taga, M.L. Tsang, T. Yasukawa, T. Kishimoto, and Y.C. Yang. 1993. Involvement of interleukin-6 signal transducer gp130 in interleukin-11-mediated signal transduction. J. Immunol. 151:2555-2561.

23. Gearing, D.P., M.P. Comeau, D.J. Friend, S.D. Gimpel, C.J. Thut, J. McGourty, K.K. Brasher, J.A. King, S. Gillis, B. Mosley, et al. 1992. The IL-6 signal transducer, gp130: an oncostatin $\mathrm{M}$ receptor and affinity converter for the LIF receptor. Science (Wash. DC). 255:1434-1437.

24. Gearing, D.P. 1993. The leukemia inhibitory factor and its receptor. Adv. Immunol. 53:31-58.

25. Thoma, B., T.A. Bird, D.J. Friend, D.P. Gearing, and S.K. Dower. 1994. Oncostatin $\mathrm{M}$ and leukemia inhibitory factor trigger overlapping and different signals through partially shared receptor complexes. J. Biol. Chem. 269:62156222.

26. Mosley, B., C. De Imus, D. Friend, N. Boiani, B. Thoma, L.S. Park, and D. Cosman. 1996. Dual oncostatin M (OSM) receptors. Cloning and characterization of alternative signaling subunit conferring OSM-specific receptor activation. J. Biol. Chem. 271:32635-32643.

27. Taga, T., M. Narazaki, K. Yasukawa, T. Saito, D. Miki, M. Hamaguchi, S. Davis, M. Shoyab, G.D. Yancopoulos, and T. Kishimoto. 1992. Functional inhibition of hematopoietic and neurotrophic cytokines by blocking the interleukin signal transducer gp130. Proc. Natl. Acad. Sci. USA. 89:10998-11001.

28. Murakami, M., M. Hibi, N. Nakagawa, T. Nakagawa, K. Yasukawa, K. Yamanishi, T. Taga, and T. Kishimoto. 1993. IL-6 induced homodimerization of gp130 and associated activation of a tyrosine kinase. Science (Wash. DC). 260: $1808-1810$.

29. Ray, D.W., S.G. Ren, and S. Melmed. 1996. Leukemia inhibitory factor (LIF) stimulates proopiomelanocortin (POMC) expression in a corticotroph cell line. J. Clin. Invest. 97:1852-1859.

30. Stefana, B., D.W. Ray, and S. Melmed. 1996. Leukemia inhibitory factor induces differentiation of pituitary corticotroph function: an immuno-neuroendocrine phenotypic switch. Proc. Natl. Acad. Sci. USA. 93:12502-12506.

31. Bousquet, C., D.W. Ray, and S. Melmed. 1997. A common pro-opiomelanocortin-binding element mediates leukemia inhibitory factor and corticotropin-releasing hormone transcriptional synergy. J. Biol. Chem. 272:10551-10557.

32. Akita, S., J. Malkin, and S. Melmed. 1996. Disrupted murine leukemia inhibitory factor (LIF) gene attenuates adrenocorticotrophic hormone (ACTH) secretion. Endocrinology. 137:3140-3143.

33. Shimon, I., J.E. Taylor, J. Dong, R.A. Bitonte, S. Kim, B. Morgan, D.H. Coy, M.D. Culler, and S. Melmed. 1997. Somatostatin receptor subtype specificity in human fetal pituitary cultures: differential role of SSTR2 and SSTR5 for growth hormone, thyroid-stimulating hormone and prolactin regulation. $J$. Clin. Invest. 99:789-798.

34. DeNoto, F.M., D.D. Moore, and H.M. Goodman. 1981. Human growth hormone DNA sequence and mRNA structure: possible alternative splicing. Nucleic Acids Res. 9:3719-3730.

35. Yamasaki, K., T. Taga, Y. Hirata, H. Yawata, Y. Kawanishi, B. Seed, T. Taniguchi, T. Hirano, and T. Kishimoto. 1988. Cloning and expression of the human interleukin-6 (BSF-2/INFß 2) receptor. Science (Wash. DC). 241:825-828.

36. Vita, N., P. Laurent, S. Lefort, P. Chalon, J.M. Lelias, M. Kaghad, G. Le
Fur, D. Caput, and P. Ferrara. 1993. Primary structure and functional expression of mouse pituitary and human brain corticotrophin releasing factor receptors. FEBS Lett. 335:1-5.

37. Orth, D.N. 1992. Corticotropin-releasing hormone in humans. Endocr. Rev. 13:164-191.

38. Cochet, M., A.C.Y. Chang, and S.N. Cohen. 1982. Characterization of the structural gene and putative 5 '-regulatory sequences for human proopiomelanocortin. Nature (Lond.). 297:335-337.

39. Asa, S.L., K. Kovacs, and W. Singer. 1991. Human fetal adenohypophysis: morphological and functional analysis in vitro. Neuroendocrinology. 53: $562-572$.

40. Spangelo, B.L., A.M. Judd, P.C. Isakson, and R.M. MacLeod. 1989. Interleukin-6 stimulates anterior pituitary hormone release in vitro. Endocrinology. 125:575-577.

41. Yamaguchi, M., N. Matsuzaki, K. Hirota, A. Miyake, and O. Tanizawa 1990. Interleukin 6 possibly induced by interleukin $1 \beta$ in the pituitary gland stimulates the release of gonadotropins and prolactin. Acta Endocrinol (Copenh.). 122:201-205.

42. Lyson, K., and S.M. McCann. 1991. The effect of interleukin-6 on pituitary hormone release in vivo and in vitro. Neuroendocrinology. 54:262-266.

43. Matta, S.G., J. Weatherbee, and B.M. Sharp. 1992. A central mechanism is involved in the secretion of ACTH in response to IL-6 in rats: comparison to and interaction with IL-1 beta. Neuroendocrinology. 56:516-525.

44. Woloski, B.M., E.M. Smith, W.J. Meyer III, G.M. Fuller, and J.E. Blalock. 1985. Corticotropin-releasing activity of monokines. Science (Wash. DC). 230:1035-1036.

45. Carmeliet, P. 1990. Interleukin-6. A putative mediator of anterior pituitary hormone secretion during the stress of infection. Trend. Endocrinol. Metab. 1:237-238.

46. Spinedi, E., R. Hadid, T. Daneva, and R.C. Gaillard. 1992. Cytokines stimulate the $\mathrm{CRH}$ but not the vasopressin neuronal system: evidence for a median eminence site of interleukin-6 action. Neuroendocrinology. 56:46-53.

47. Navarra, P.L., S. Tsagarakis, M. Faria, L.H. Rees, G.M. Besser, and A Grossman. 1991. Interleukins-1 and -6 stimulate the release of CRH-41 from the rat hypothalamus in vitro via the eicosanoid cyclo-oxygenase pathway. Endocrinology. 128:37-41.

48. Vankelecom, H., P. Carmeliet, J. Van Damme, A. Billiau, and C. Denef 1989. Production of interleukin-6 by folliculo-stellate cells of the anterior pituitary gland in a histiotypic cell aggregate culture system. Neuroendocrinology. 49:102-106.

49. Vankelecom, H., P. Matthys, J. Van Damme, H. Heremans, A. Billiau, and C. Denef. 1993. Immunocytochemical evidence that S-100-positive cells of the mouse anterior pituitary contain interleukin-6 immunoreactivity. J. Histochem. Cytochem. 41:151-156.

50. Carmeliet, P., H. Vankelecom, J. Van Damme, A. Billiau, and C. Denef. 1991. Release of interleukin-6 from anterior pituitary cell aggregates: developmental pattern and modulation by glucocorticoids and forskolin. Neuroendocrinology. 53:29-34.

51. Stahl, N., and G.D. Yancopoulos. 1993. The alphas, betas, and kinases of cytokine receptor complexes. Cell. 74:587-590.

52. Liu, J., B. Mordell, A. Aruffo, J.S. Marken, T. Taga, K. Yasukawa, M. Murakami, T. Kishimoto, and M. Shoyab. 1992. Interleukin-6 signal transducer gp130 mediates oncostatin M signaling. J. Biol. Chem. 267:16763-16766. 